\title{
Vulkansk aktivitet \\ - anden halvdel af 2009
}

Af geolog Susanne Plesner, GeologiskNyt

Vores ellers så trofaste europæiske vulkaner Etna og Stromboli har ikke gjort væsen nok af sig til at have fundet vej til den ugentlige opdatering fra USGS $i$ andet halvår af 2009. Derimod har andre gamle kendinge som Mayon, Soufriere Hills og Nyamuragira repræsenterende tre forskellige dele af Verden, været relativt aktive.

Aktiviteten har blandt andet resulteret i evakueringer af en del mennesker, og Nyamuragira i den Demokratiske Republik Congo truer i skrivende stund dyrelivet i den nærliggende nationalpark Virunga.

Den seneste tids aktivitet fra Mayon, Soufriere Hills og Nyamuragira er beskrevet kort nedenfor.

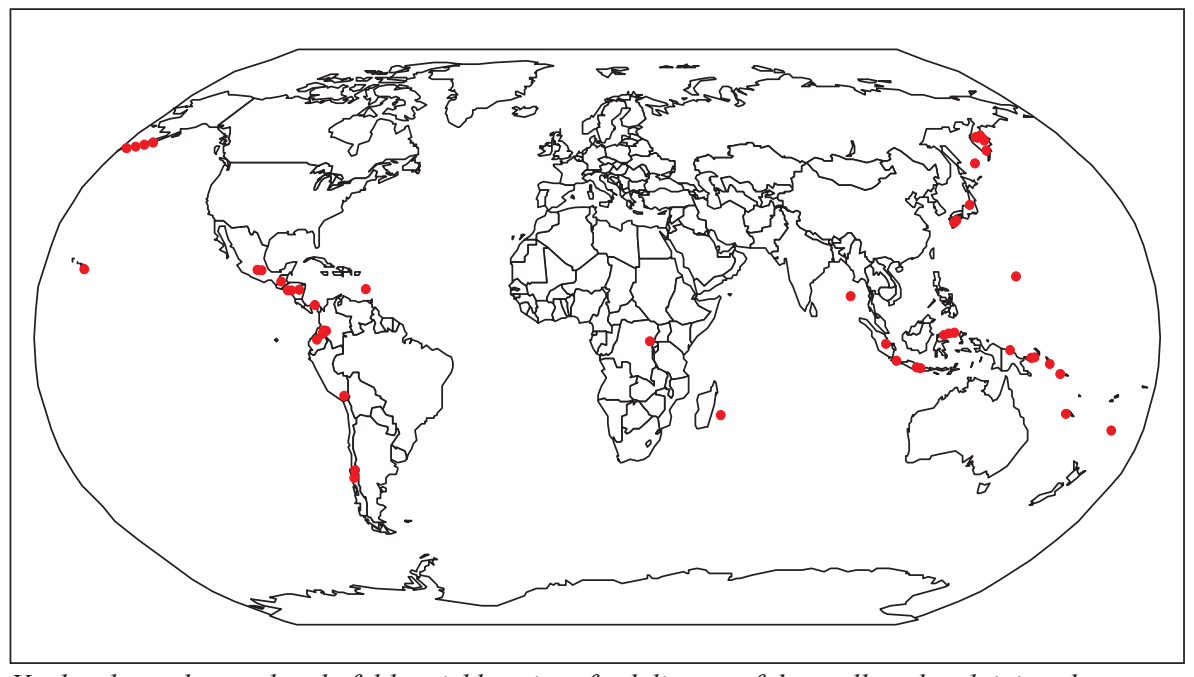

Verdenskort, der med røde fyldte cirkler viser fordelingen af den vulkanske aktivitet de seneste seks måneder. (Grafik: Forfatteren)

Mayon

I første halvår af 2009 målte man forhøjet seismisk aktivitet fra Mayon, hvilket fik igangsat målinger af højden af topområdets

\section{Vulkansk aktivitet de sidste 6 måneder}

Nordlige Stillehavsregion

Kilauea, Hawaii, USA

Redoubt, Alaska, USA

Shishaldin, Aleuterne, USA

Cleveland, Alaska

Pagan, Mariana Island

Suwanose-Jima, Ryukyu Øerne, Japan

Sakura-Jima, Kyushu, Japan

Ebeko, Paramushir Island

Karangetang, Indonesien

Dukono, Indonesien

IBU, Halmahera

Kolokol Group, Urup Islands

Mayon, Luzon, Filippinerne

\section{Sydlige Stillehavsregion}

Semeru, Java, Indonesien

Batu Tara, Indonesien

Krakatau, Indonesien

Rinjani, Indonesien

Dieng volcanic complex, Java, Indonesien

Slamet, Indonesion

Batur, Bali, Indonesien

Ambrym, Vanuatu

Bagana, Papua Ny Guinea
Rabaul, Papua Ny Guinea

Manam, Papua Ny Guinea

Sakar, Ny Guinea

Karkar, Ny Guinea

Langila, New Britain

Gaua, Banks Islands

Mellemamerika, Mexico og Vestindien
Concepción, Nicaragua
Arenal, Costa Rica
Poas, Costa Rica
Turrialba, Costa Rica
Colima, Mexico
Popocatépetl, Mexico
Fuego, Guatemala
Santa María, Guatemala
Pacaya, Guatamala
Soufriere Hills, Montserrat
San Cristobal, Nicaragua
San Miguel, El Salvador
San Vicente, El Salvador
Sydamerika
Tungurahua, Ecuador
Reventador, Ecuador

Sangay, Ecuador

Galeras, Colombia

Nevado del Huila, Colombia

Llaima, Chile

Chaiten, Chile

Ubinas, Peru

\section{Rusland}

Karymsky, Kamchatka

Shiveluch, Kamchatka

Benzymianny, Kamchatka

Kliuchevskoi, Kamchatka

Koryaksky, Kamchatka

Kizimen, Kamchatka

Sarychev Peak, Matua Island

\section{Afrika \& Mellemøsten}

Nyamuragira, Demokratiske Republik Congo Manda Hararo, Etiopien

Erta Ale, Etiopien

Indiske ocean

Piton de la Fournaise, Reunion

Barren Island, Andaman Islands, Indien 


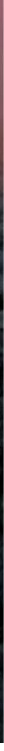

Erta Ale, som ligger i Etiopien, var ret aktiv i november og december. Dette foto er fra 2008. (Foto: Tom Pfeiffer)

hvidglødende masser. Her fandt man ud af, at de begyndende hævninger af området, som var blevet målt tidligere på året, var bibeholdt.

I august begynder man at registrere jordskælv i området, og i september og oktober kommer der udbrud med damp og askeeksplosioner til. I midten af november observerer man fra flere steder hvidglødende bjergartsfragmenter forlade topområdet af vulkanen og bevæge sig ned ad siderne. Det får myndighederne til at evakuere ca. 700 familier fra de berørte skråninger.

Hyppighed og styrke af eksplosioner og udbrud (herunder store emissioner af $\mathrm{SO}_{2}$ ) intensiveres op gennem december måned frem til 20. december, hvor de første lavafontæner ses fra toppen af vulkanen. Op mod 50.000 mennesker er nu evakueret og ad- varselsniveauet hævet til 4 ud af 5 mulige. Udbruddene fortsætter frem til slutningen af december, hvor de langsomt aftager igen.

\section{Soufriere Hills}

I perioden fra oktober og frem til årets slutning har aktiviteten fra Soufriere Hills skiftet mellem, at der ikke er sket så meget over fredelige askeudbrud til pyroklastiske strømme, der er løbet ned langs vulkanens sider. En lavadome er desuden blevet dannet i vulkanens topkrater. I slutningen af december var askeudbruddene så voldsomme, at der faldt aske på flere andre af de Caribiske øer. 45 fly til og fra lufthavnen i Puerto Rico $400 \mathrm{~km}$ fra vulkanen måtte aflyses. Hverken lavastrømme eller pyroklastiske strømme er nået så langt, at evakueringer har været nødvendige.

\section{Nyamuragira}

Nyamuragira er en af Afrikas mest aktive vulkaner. Den 2. januar 2010 begyndte et udbrud fra en sprække på vulkanens SØ-side og dagen efter var en $15 \mathrm{~m}$ bred lavastrøm flydt 4,6 km ned mod Virunga National Park, der huser truede chimpanser. Udbruddet startede med en stor eksplosion, hvorefter lavaen strømmede ud som fontæner og med efterfølgende lavastrømme.

\section{Relevante links:}

http://www.volcano.si.edu/reports/usgs/index.cfm?content=archive

http://volcano.und.nodak.edu/

http://nwrota2009.blogspot.com/ 